\title{
I Gymnastikkbygningen
}

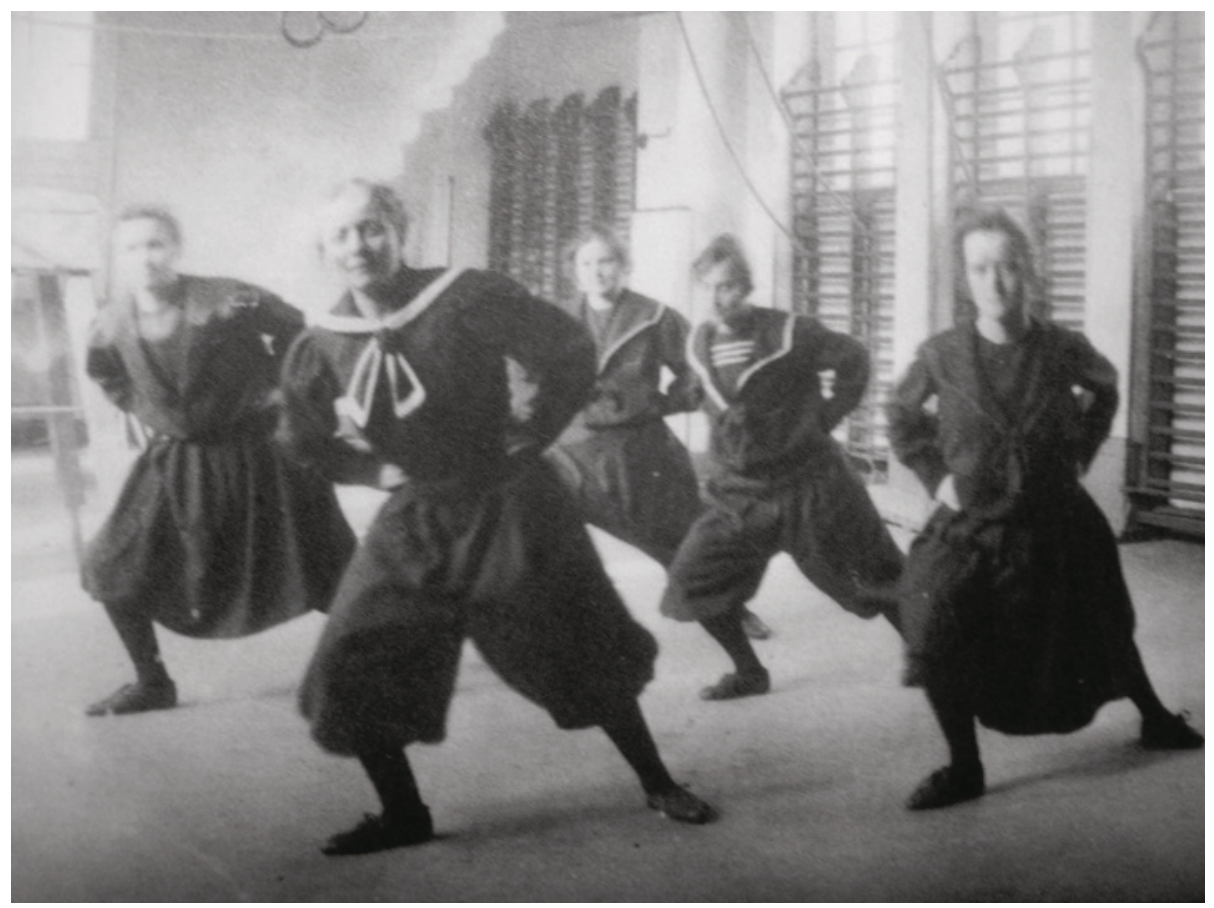

Foto: Museum for universitets- og vitenskapshistorie, Universitetet i Oslo. Fotograf ukjent

Universitetshagen i Oslo sentrum inneholder flere historisk interessante bygninger som nå er under rehabilitering, for eksempel «Professorboligen» og «Gymnastikkbygningen». I sistnevnte ble i 1896 det første gymnastikkurset for kvinnelige studenter igangsatt. Foran til venstre ser vi førsteårs medisinstudent Marta Nordlid. Hun skal ha uttalt at studiet var så krevende fysisk og psykisk at ukentlig trening var nødvendig for å kunne gjennomføre det (1). Av folketellingen fra år 1900 kan man se at hun bodde i Maridalsveien 73. Marta NordlidHansen (1876-1951) ble cand.med. i juni 1905 (2). Fra 20. november samme år prak- tiserte hun i Kviteseid i Vest-Telemark. Ektemannen var «bokhandlar og kaupmann». Paret fikk tre barn.

\section{Jacob Klafstad \\ jklaf@broadpark.no}

Jacob M. Klafstad (f. 1934) er lege og tannlege, pensjonert spesialist i maxillofacial kirurgi og tidligere medisinsk hovedlærer ved Våpenskolen for Hærens sanitet samt stabslege for Sjøforsvaret.

Forfatter har fylt ut ICMJE-skjemaet og oppgir ingen interessekonflikter.
Litteratur

1. Kalender 2007. Oslo: Universitetet i Oslo, 2007.

2. Larsen $\emptyset$, red. Norges leger. Bd. IV. Oslo: Den norske legeforening, 1996.

Mottatt 2.2. 2015 og godkjent 20.4. 2015. Redaktør: Lise Mørkved Helsingen. 